\title{
I Like Snakes!
}

By JOYCE DEW, Museum Extension Services, Regina

An indignant three year old stole the show on me once when I glibly recited at a Christmas concert, "Ugh, I hate pigs, they are dirty things." A child's piping young voice exclaimed, "They are not! I like pigs." I think I know how that child felt, for when people draw back in disgust from a perfectly harmless snake and say, "How can you touch the horrible thing?" I feel like replying, "It is not horrible. I like snakes."

Perhaps if my experience with Cedric, the Bull snake and the only snake I have come to know well, had not been a pleasant one, I, too, would have the same antipathy towards snakes that is displayed by so many people. I am sure that being bit by a venomous snake is a rather disquieting experience, and it is true that a woman died recently in Ontario from snake bite. It is a rather unbelievable thought that irate citizens of that Ontario community demand that ALL snakes be killed to prevent the further destruction of human life from snake bite! Certainly more people are killed in this country by being shot as the result of hunting accidents than die from the venom of a snake. I have yet to hear someone suggest the eradication of all hunters as a way of preventing hunting accidents.

Not only are the vast majority of snakes in Saskatchewan non-poisonous, but they are beneficial to the farmer as well, killing many harmful insects and rodents. How then does one explain the general dislikes for snakes? It is expected that women should be terrified at the sight of reptiles, mice and such inhabitants of the animal kingdom, but it came as a bit of a surprise to me that men are perhaps even more squeamish about snakes than are women. This, I think, is a learned reaction and not an inborn one. I have seen very small children, who have never heard of a snake, go to one with no emotion other than curiosity. Likewise, I have seen a child reach out to touch a snake, only to have a horrified parent say, "Come away. Don't touch the horrible thing." True, since there are a few poisonous
Rattlesnakes in the southern part of our province, it is wise to warn small children to keep away from snakes until they are old enough to differentiate between the harmless and the harmful ones, but is it necessary to develop within them an unreasonable fear of all snakes?

Most cats and dogs will resist teasing and bite their tormentors, and they are perfectly justified in doing so. Herpetologists who have handled snakes all their lives declare that some snakes cannot be induced to bite. As is the case of the Bull Snake, the teeth are not used for biting and chewing, but are recurved and are used only to keep the prey, which is swallowed whole, from slipping out of the mouth. A Bull Snake, when first captured, will open its mouth and hiss loudly, at the same time vibrating its tail in the grass, thus making a rustling sound. As far as this species of snake is concerned, its behaviour is mostly bluff and is meant to intimidate the enemy. It usually succeeds, too, for that is how Cedric got himself into trouble and was brought as a result to the museum. He first attracted attention to himself by engaging in the innocent pastime of chasing a terrified dog across the lawn. Shortly after that he found himself enclosed in one of the museum's show cases, and has remained there more or less ever since, except when being shown to groups.

Another prairie snake, the Hognosed Snake, is an even greater bluffer than is the Bull Snake. If it finds that hissing and looking fierce fails to frighten away its tormentor, it will play dead, and since all respectable snakes are bottom side up when dead it assumes that pose. If you pick up its limp, "lifeless" body and place the snake back on the ground right side up, it will promptly roll over "dead" again, thus giving the game away by playing it too well.

On hot summer days it was refreshing to pick Cedric up if he had been in a cool spot, for he was deliciously cool to touch. If, on the other hand, he had been basking in 
the hot sun, he felt warm indeed. Being cold blooded does have its disadvantages if you are a snake. Have you ever considered how inconvenient it would be if you could only digest your food when the temperature of your surroundings was within a certain limited range? Some snakes are affected that way. We could understand Cedric's not eating cold beef when he was accustomed to eating only live food. but we wondered at his vomiting it back up once it was in his stomach. Warming Cedric up to a cozy 80 degrees before feeding him solved the problem. Then the digestive juices were able to accomplish their task, and a two month's fast was broken. A fast cif that length is no record for a snake; some snakes do not eat for a year after they are born.

Our native Saskatchewan snakes, including the Smooth Green Snake, Garter Snake, Red-bellied Snake, Bull Snake and Hognosed Snake, are for the most part easily tamed and make excellent pets. The only poisonous snake found in Saskatchewan, the Prairie Rattler, is confined to the southern areas and is readily distinguishable by the rattles on its tail. The Bull Snake will, by vigorously vibrating its tail in dried weeds, make a convincing enough rattle to frighten away the uninitiated. Cedric, who ordinarily is most docile and never emits a hiss from one month to the next, reacted violently recently when he saw a dog. It was hard to believe that such a docile snake could put on such a ferocious appearance. It took him fifteen minutes to subside and resume a more harmless demeanour. It certainly was an impressive sight, even though I suspected that Cedric didn't mean a hiss of it but sincerely hoped the dog would take the warning to heart.

At present, Cedric, a live Bull Snake, is on display at the museum. Since life is an indeterminate factor with snakes, as with the human species, we cannot guarantee that Cedric will always be on display alive. However, all the snakes mentioned in this article are on display in a stuffed condition. I might add that Cedric has the habit of remain. ing so motionless that he too is frequently mistaken for the stuffed article. Such indignities Cedric takes unblinkingly. You would, too, if you had no eyelids.

Note: Cedric, the Bull Snake, has played an important role in the museum's educational program; some 6,000 school children having handled this snake in the past 12 months. All school groups touring the museum now enjoy the benefits of numerous tactile-aids, an activity aimed at achieving a more intimate contact between the audience and the subject.

\section{Meteors and Meteorites}

\section{By JOHN HODGES, Regina Astronomical Society}

The opportunities that remain for amateur research in astronomy are getting fewer in number each year. There are very few subjects that the amateur can investigate with the krowledge that he can be of help to the professional. Any society has thereiore to select from a very narrow range of endeavours. The Regina "star gazers" have selected meteors and meteorites as their particular study because they know that the professional is always glad to hear about observations of these visitors from space. We can say that in this field the more observers the better. At any one location, an observer sees only one one hundred thousandth of the visible sky. This leaves considerable room for more amateurs, a very happy situation.

For six years, the Regina group has watched the meteors that appear to radiate from the constellation of Perseus about the middle of August. So far we have logged about two thousand of these meteors, recording identity, brilliance, characteristics of flight, and colour. As we gained experience in this field, we were able to get some good photographs. The first Spectrogram taken by amateurs in Canada was obtained in August, 1955. A spectrogram is a picture which enables the material in a meteor to be identified, after the 